\title{
Analisis Kolorimetri Kadar Hemoglobin Darah dengan Metode Pencitraan Digital Menggunakan Desktop Scanner
}

\author{
Koekoeh Santoso ${ }^{1}$, Muhammad Agil ${ }^{2}$, Ridzky Pratama ${ }^{3}$ \\ ${ }^{1}$ Departemen Anatomi Fisiologi dan Farmakologi, Fakultas Kedokteran Hewan, Institut Pertanian Bogor \\ ${ }^{2}$ Departemen Klinik Reproduksi dan Patologi, Fakultas Kedokteran Hewan, Institut Pertanian Bogor \\ ${ }^{3}$ Program Pendidikan Profesi Dokter Hewan, Fakultas Kedokteran Hewan, Institut Pertanian Bogor
}

ABSTRAK: Spektrofotometer adalah sistem baku berbasis kolorimetri dalam pengukuran kadar Hemoglobin (Hb). Penggunaan scanner untuk mengukur kadar $\mathrm{Hb}$ berbasis kolorimetri telah dilakukan sebagai sistem alternatif. Kurva baku kanal warna scanner yang paling curam adalah blue. Perbandingan kurva baku spektrofotometer dengan kanal warna blue menunjukan nilai $\mathrm{y}=0.3131 \mathrm{x}+0.0565$ dengan $\mathrm{R}^{2}=0.9954$ dan angka konversi nilai absorbansi desktop scanner menjadi kadar Hb adalah 73.6. Hasil uji Pasangan T menghasilkan nilai p sebesar 0.325 atau tidak berbeda nyata pada $\mathrm{p}>0.05$.

Kata kunci:

desktop scanner, imageJ, kadar hemoglobin, kolorimetri.

\section{- PENDAHULUAN}

Spektrofotometer adalah sistem baku dalam pengukuran kadar Hemoglobin (Hb) berbasis kolorimetri (Ohta dan Roberton 2005; Frankhauser 2007), namun mahal dan memerlukan tenaga ahli, sehingga diperlukan sistem alternatif berbasis kolorimetri yang murah, mudah, dan cepat yaitu dengan memanfaatkan desktop scanner dan teknik pengolahan dan pengukuran citra menggunakan ImageJ.

\section{- BAHAN DAN METODE}

Sebanyak $120 \mu \mathrm{l}$ darah kelinci ditambahkan dalam tabung reaksi berisi $30 \mathrm{ml}$ reagen Drabkin yang dimodifikasi (Rezende et al. 2006), kemudian diencerkan dengan reagen hingga konsentrasi $100 \%, 90 \%, 80 \%$, 70\%, 60\%, dan $50 \%$ dalam tabung terpisah untuk membuat kurva standar. Masing-masing larutan diukur absorbansinya dengan spektrofotometer Hitachi U-2001 pada panjang gelombang $540 \mathrm{~nm}$. Dari masing-masing tabung tersebut diambil $25 \mu 1$ kesumur microplate dengan 5 kali pengulangan untuk dipindai menggunakan desktop scanner $\mathrm{HP}{ }^{\circledR}$ Scanjet 7490c dan disimpan dalam bentuk tagged image file format (TIFF) agar dapat diproses dan diukur absorbansinya menggunakan ImageJ. Kadar $\mathrm{Hb}$ diperoleh dengan rumus $\mathrm{Hb}=\mathrm{Abs} \times 36.8$ $\mathrm{g} / \mathrm{dL}$. Hasil ini digunakan untuk mendapatkan konstanta yang digunakan melakukan konversi absorbansi desktop scanner menjadi kadar $\mathrm{Hb}$. Analisa kuantitatif dilakukan menggunakan program Microsoft Excel 2010 untuk membuat grafik dan uji pasangan T menggunakan SPSS 19.0.

\section{— HASIL DAN PEMBAHASAN}

Pengukuran absorbansi larutan yang diencerkan hingga konsentrasi $100 \%, 90 \%, 80 \%, 70 \%, 60 \%$, dan $50 \%$ dengan spektrofotometer menghasilkan kurva absorbansi $\mathrm{y}=$ $0.00047 \times-0.0222$ dengan $\mathrm{R}^{2}=0.9992$ (Gambar 1). Scanner telah digunakan untuk mengukur glukosa, kolesterol, dan kreatinin darah (De Morais dan De Lima 2014); diagnosa atherosklerosis (Mann et al. 2015); serta kandungan pati pada kentang (Matthews et al. 2004).

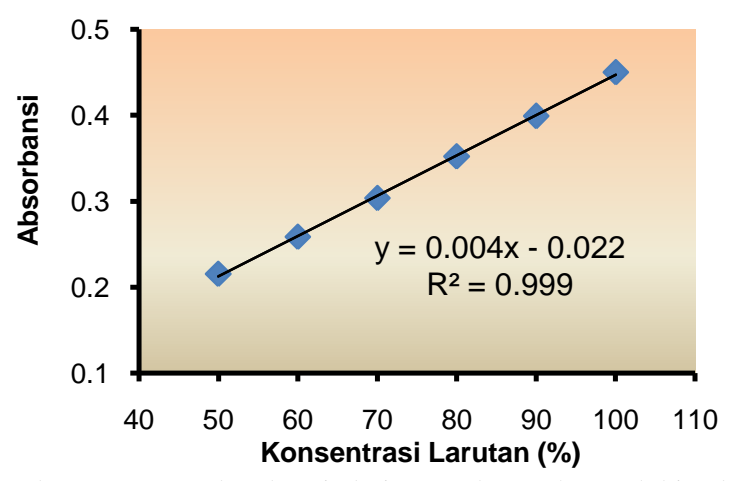

Gambar 1 Kurva absorbansi dari pengukuran hemoglobin darah kelinci menggunakan spektrofotometer

Hasil pengukuran menggunakan scanner menghasilkan kurva absorbansi untuk warna $R /$ red, G/green, dan $B /$ blue

\footnotetext{
Diterima : 28 Juli 2017

Direvisi : 14 Agustus 2017

Disetujui : 16 Agustus 2017
} 
dengan kemiringan paling curam adalah B/blue (Gambar 2), sehingga dipilih untuk perhitungan selanjutnya karena kanal warna tersebut paling sensitif terhadap perubahan konsentrasi Hb (De Morais dan De Lima 2014).

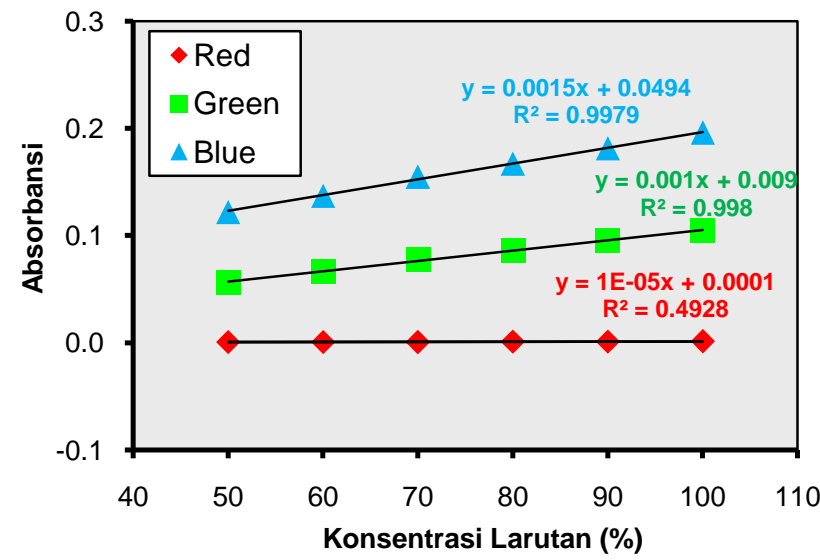

Gambar 2 Kurva absorbansi dari pengukuran hemoglobin darah kelinci menggunakan scanner pada kanal warna Red, Green dan Blue

Hasil perbandingan absorbansi spektrofotometer dengandesktop scanner menunjukan $\mathrm{y}=0.3131 \mathrm{x}+0.0565$ dengan $\mathrm{R}^{2}=0.9954$ dan diperoleh konstanta 73.6 untuk mengubahnilai absorbansi desktop scanner menjadi kadar $\mathrm{Hb}$. Perbandingan kadar $\mathrm{Hb}$ dari scanner dan spektrofotometer dapat dilihat di Tabel 1. Hasil uji pasangan T menghasilkan nilai p sebesar 0.325 .

Tabel 1 Absorbansi dan kadar hemoglobin darah kelinci yang didapatkan dari scanner dan spektrofotometer

\begin{tabular}{|ccccc|}
\hline $\begin{array}{c}\text { Konsen- } \\
\text { trasi (\%) }\end{array}$ & $\begin{array}{c}\text { Abs } \\
\text { Spektro }\end{array}$ & $\begin{array}{c}\text { Abs } \\
\text { Scanner }\end{array}$ & $\begin{array}{c}\text { Hb } \\
\text { Spektro } \\
\text { (g/dL) }\end{array}$ & $\begin{array}{c}\text { Hb } \\
\text { Scanner } \\
\text { (g/dL) }\end{array}$ \\
\hline 100 & $0.5 \pm 0.08$ & $0.2 \pm 0.03$ & $16.6 \pm 2.85$ & $14.4 \pm 2.36$ \\
90 & $0.4 \pm 0.07$ & $0.2 \pm 0.03$ & $14.7 \pm 2.41$ & $13.4 \pm 2.02$ \\
80 & $0.4 \pm 0.06$ & $0.2 \pm 0.03$ & $12.9 \pm 2.21$ & $12.3 \pm 2.03$ \\
70 & $0.3 \pm 0.05$ & $0.2 \pm 0.02$ & $11.2 \pm 1.75$ & $11.4 \pm 1.75$ \\
60 & $0.3 \pm 0.03$ & $0.1 \pm 0.02$ & $9.5 \pm 1.29$ & $10.1 \pm 1.27$ \\
50 & $0.2 \pm 0.03$ & $0.1 \pm 0.02$ & $7.9 \pm 1.06$ & $8.9 \pm 1.18$ \\
\hline
\end{tabular}

\section{- SIMPULAN}

Kadar hemoglobin yang didapat dengan scanner dan spektrofotometer tidak ditemukan perbedaan yang signifikan pada tingkat kepercayaan $95 \%$.

\section{- INFORMASI PENULIS}

Penulis untuk Korespondensi

koekoehipb@gmail.com

Persetujuan Penulis

Semua penulis telah memberikan persetujuan terhadap versi akhir dari naskah ini.

\section{- UCAPAN TERIMA KASIH}

Penulis berterima kasih kepada Laboratorium Fisiologi, Fakultas Kedokteran Hewan, Institut Pertanian Bogor.

\section{- PUSTAKA ACUAN}

De Morais CLM, De Lima KMG. 2014. A colorimetric microwell method using a desktop scanner for biochemical assays. Talanta. 126:145-150.

Frankhauser DB. 2007. Spectrophotometer use. http://biology.clc.uc.edu/fankhauser/Labs/Microbiology/Growt h_Curve/Spectrophotometer.htm [diunduh 6 Februari 2015].

Kohl SK, Landmark JD, Stickle DF. 2006. Demonstration of absorbance using digital color image analysis and colored solutions. J ChemEdu 83(4):644-646.

Mann E, Kolusheva S, Yossef R, Porgador A, Aviram M, Jelinek R. 2015. Colorimetric polymer assay for the diagnosis of plasma lipids atherogenic quality in hypercholesterolemic patients.Mol. Diagn. Ther. 19:35-43.

Matthews KR, Landmark JD, Stickle DF. 2004. Quantitative assay for starch by colorimetry using a desktop scanner. J ChemEdu. 81(5):702-704.

Ohta N, Robertson A. 2005. Colorimetry: Fundamentals and Applications. West Sussex(GB): JohnWiley\& Sons Ltd.

Rezende EI, Gomes FR, Malisch JL, Chappell MA, Garland T. 2006. Maximal oxygen consumption in realtion to subordinate traits in lines of house mice selectively bred for high voluntary wheel running. J Appl Physiol. 101:477-485. 